\title{
Consensus Statement on Submission and Publication of Manuscripts
}

With the aim to unify and harmonize the guidelines for the prevention of fraudulent submission and publication practice, the subscribing group of editors of surgical journals agreed upon definitions which are summarized in the following Consensus Statement.

We feel strongly that worldwide acceptance of these principles will enhance alertness of authors, editors and publishers against an increasing amount of duplicate and fraudulent publications.

We hope that you as our readers and authors will commit yourself to supporting these guidelines thereby helping to avoid negligence and malpractice in the publication of surgical science.

M.W. Büchler, Bern

E.H. Farthmann, Freiburg

\section{Duplicate Submission and Publication}

In general, if a manuscript has been peer-reviewed and published, any subsequent publication is duplication.

Exceptions to this general rule may be:

(a) Prior publication in meeting program abstract booklets or expanded abstracts such as those published by the Surgical Forum of the American College of Surgeons or Transplantation Proceedings. However, these must be referenced in the final manuscript.

(b)A manuscript which extends an original database (a good rule might be expansion by $50 \%$ or more) or which analyzes the original database in a different way in order to prove or disprove a different hypothesis. Previous manuscripts reporting the original database must, however, be referenced.

(c) Manuscripts which have been published originally in non-English-language journals, provided that the prior publication is clearly indicated on the English-language submission and referenced in the manuscript. In some circumstances, permission to publish may need to be obtained from the non-English-language journal.

For example, any submission duplicating material previously published in full in 'Proceedings' or book chapters is considered duplicate unless the exceptions in (a) above apply. Similarly, manuscripts dealing with subgroups of data (i.e. patients) that have previously been analyzed, discussed and published as a larger group are considered duplicate unless (b) above applies.

The Internet raises special concerns. If data have previously appeared on the Internet, submission of those data for publication is considered duplication. If Internet publication follows journal publication, the journal publication should be clearly referenced. Some journals may provide early Internet publication of accepted peerreviewed papers which are subsequently published in that journal. This does not constitute duplication if both manuscripts are identical and covered by the same single copyright.

\begin{tabular}{ll}
\hline KARGER & ( ) 2001 S. Karger AG, Basel \\
Fax +41613061234 & \\
$\begin{array}{l}\text { E-Mail karger@karger.ch } \\
\text { www.karger.com }\end{array}$ & $\begin{array}{l}\text { Accessible online at: } \\
\text { www.karger.com/journals/dsu }\end{array}$
\end{tabular}




\section{Fraudulent Publication}

The following activities are examples of fraudulent publication practices:

(a) Willful and knowing submission of false data for publication.

(b) Submission of data from sources not the author's (or authors') own.

(c) Falsely certifying that the submitted work is original and has not been submitted to, or accepted by, another journal.

(d)Sponsoring or vouching for a manuscript containing data over which the sponsor has no control or knowledge.

(e) Allowing one's name to appear as an author without having contributed significantly to the study.

(f) Adding an author's name to a manuscript to which he/ she has not contributed, or reviewed or agreed to in its current form.

(g) Flagrant omission of reference to work of other investigators which established their priority.

(h)Falsification of any item on the copyright form.

(i) Failure to disclose potential conflict of interest with a sponsoring agency.

While not intended as an all-inclusive document, these examples and guidelines should alert authors to potential problems that should be avoided when they are considering submission of a manuscript to a peer-reviewed journal.
American Journal of Surgery

American Surgeon

Annals of Surgery

Annals of Surgical Oncology

Current Surgery

Digestive Surgery

Diseases of the Colon and Rectum

Journal of the American College of Surgeons

Journal of Gastrointestinal Surgery

Journal of Japan Medical Association

Journal of Japan Society for Endoscopic Surgery

Journal of Japan Surgical Association

Journal of Pediatric Surgery

Journal of Surgical Research

Journal of Thoracic and

Cardiovascular Surgery

Journal of Vascular Surgery

Journal of Parenteral and

Enteral Nutrition

Journal of Trauma

Surgery

Surgical Endoscopy

Surgical Laparoscopy, Endoscopy and Percutaneous Techniques World Journal of Surgery

Zentralblatt für Chirurgie
Hiram C. Polk, Jr., MD

Talmadge A. Bowden, Jr., MD

Layton F. Rikkers, MD

Charles M. Balch, MD

Walter J. Pories, MD

Markus W. Büchler, MD

Eduard H. Farthmann, MD

Victor Fazio, MD

Seymour Schwartz, MD

John L. Cameron, MD

Keith A. Kelly, MD

Yasuo Idezuki, MD

Yasuo Idezuki, MD

Yasuo Idezuki, MD

Jay Grosfeld, MD

Wiley W. Souba, MD

David W. McFadden, MD

Andrew S. Wechsler, MD

Robert B. Rutherford, MD

K. Wayne Johnston, MD

Danny O. Jacobs, MD

Basil A. Pruitt, Jr., MD

Andrew L. Warshaw, MD

Michael Sarr, MD

Bruce V. MacFadyen, Jr., MD

Sir Alfred Cuschieri, MD

Carol E.H. Scott-Conner, MD, PhD

Maurice Arregui, MD

Ronald K. Tompkins, MD

Albrecht Encke, MD 